\title{
From South Asia to Southasianism: A Nepalese Activist's Perspective
}

An interview with Kanak Mani Dixit

\section{Blandine Ripert}

\section{OpenEdition}

\section{Journals}

Electronic version

URL: http://journals.openedition.org/samaj/3815

DOI: $10.4000 /$ samaj.3815

ISSN: 1960-6060

Publisher

Association pour la recherche sur l'Asie du Sud (ARAS)

Electronic reference

Blandine Ripert, «From South Asia to Southasianism: A Nepalese Activist's Perspective », South Asia Multidisciplinary Academic Journal [Online], 10 | 2014, Online since 25 December 2014, connection on 19 April 2019. URL : http://journals.openedition.org/samaj/3815 ; DOI : 10.4000/samaj.3815

This text was automatically generated on 19 April 2019

\section{cc)}

This work is licensed under a Creative Commons Attribution-NonCommercial-NoDerivatives 4.0 International License. 


\title{
From South Asia to Southasianism: A Nepalese Activist's Perspective
}

\author{
An interview with Kanak Mani Dixit
}

\author{
Blandine Ripert
}

\section{About Kanak Mani Dixit}

1 Kanak Mani Dixit is an intellectual from Nepal, a journalist since his high school days in the early 1970s in Lalitpur (Kathmandu Valley) and a well-known publisher, editor and writer. He founded the bimonthly regional magazine Himal in 1987, which became Himal Southasian when he enlarged the area it covered, as he says, 'from Afghanistan to Burma and from Tibet to the Maldives.' The magazine offers informed critical commentary on social and cultural issues in South Asia. He is also the publisher of the Nepali language political newsweekly Himal Khabarpatrika.

2 After a Bachelor of Arts degree in Katmandu and a Bachelor of Law in Delhi, he went to Columbia University where he studied international relations, then journalism (Master's Degree in both, in 1982). He worked for eight years at the United Nations Secretariat in New York, before deciding to return to Nepal in 1990. At that time, he helped bring fourcolour printing to Nepal, and also joined the effort at archiving. He played a significant role in the development of press and media in Nepal in the years after the establishment of democracy in 1990 and also involved himself in the Nepali language media. Subsequently, printing became an industry as many other presses followed his, enabling Nepal to no longer import from other countries-especially Thailand-to satisfy its printing needs, a critical factor during the period of political effervescence in the 1990s. Beyond journalism, Dixit chairs the 'Film Southasia', a documentary festival that he founded, and is also involved with the Madan Puraskar Pustakalaya archives, the Shikshyak magazine for Nepal's school teachers, the Sajha Yatayat public transport cooperative company, and the Kathmandu Valley Preservation Trust, which preserves and restores architectural heritage. He has published many children's books, including the much translated 'Adventures of a Nepali Frog'. Dixit follows a family tradition as he 
comes from a clan of several generations of writers (Dixit 2003). In the late 1990s and early 2000s, he became involved in the civil rights movement amidst the Maoist insurgency and King's Gyanendra's autocracy. He participated in the People's Movement of 2006, which led to the fall of the king's autocracy, which eventually led to the birth of the Nepali republic. His last book, Peace Politics in Nepal (2011), deals with issues related to the peace process in Nepal since 2006, notably with regard to the writing of a new Constitution for the country, which is on-going.

4 Taken together, Kanak Mani Dixit may best be described as a South Asian activist. In 2009 he was the first Nepali national to receive the Prince Claus Award from The Netherlands, honouring him for 'his outstanding contributions to public debate, for creating platforms that enable South Asians to connect, interact and network transcending national and cultural boundaries, and for his socially engaged, multi-disciplinary approach to creativity and development. ${ }^{1}$

\section{The interview}

After almost 70 years of separation between the countries of South Asia, with borders mostly closed to the movement of people and commodities, not to mention recurrent conflicts between states, what is left of the heritage of what could be today South Asia?

The heritage of Southasia is intact, but it is evolving in different directions because the restricted frontiers between most of the countries greatly do injustice to the shared historical experiences of the 'Indic' region. When Partition broke the region apart in 1947, most leaders did not believe that this would be so permanent, or at the very least thought that the borders would remain open. However, nothing of the sort happened, worst, the region was prey to several wars. In the meantime, the dominant state narrative developed on the basis of ultra-nationalism, which was a populist tool used to drive the larger populace. As a consequence, today you have a region that is culturally similar but divided by what I call the capital elites; only repeating the refrain that 'we are alike, culturally similar' will not move the regional idea forward.

You have often made an appeal for a federal South Asia, through a process that would not be top-down, and would come from the local scale. How do you think this could happen in practice without the participation of states, given the obstacles to direct contact between people? Does it mean that South Asian regionalism is mainly a question of scale?

6 The proposal for engagement between the provinces of the two larger countries, with each other and with the other smaller sovereign countries of Southasia, is an attempt to break through the nation-state logjam. To begin with, a federally devolved India and Pakistan will benefit the far-flung people of these two countries, which in my view cannot countenance a centralized state administration in the long term. If such devolution happens, providing the provinces of Pakistan and the states of India with a larger autonomy of action, much of the battle for 'Southasia' will be already won. This will also help to tackle the asymmetry in Southasian regionalism created by the size of India, in terms of population, land area, economic and geopolitical power, and geographical centrality.

If South Asia is more a 'sensibility than a geographical region,' as you wrote, how would you definite this sensibility?

7 It is important not to be trapped by determinism. With that caveat, I would say that the 'sensibility' evolves from shared history, penumbra demarcations between identities, soft 
boundaries between states/principalities, and syncretism of cultures. Going down a bylane in Peshawar or Indore, to be hit by the aroma of the same spices, to find the similar dirt and distress, perhaps can also be described as similar sensibilities. How all this translates in the relationships between individuals and communities is the display of empathy, the ability to look at issues from the point of view of the other protagonist. So, when I suggest that Southasia is more a sensibility than a geographical region, I am making an idealized (perhaps romantic) argument that in order to go beyond the coagulation of nation-statism that has all of us in its grip, we need to look at Southasia not in terms of national citizenship identities but through the sensibility of anyone who is able to look at things from the other's point of view.

Are there symbolic icons in the construction of South Asia? What seems to you to operate as cementing vectors?

8 The icons have unfortunately been overtaken by parochial national identities. To begin with, if 'India' had not been taken over by the nation-state of India in 1947, we would not have to import a geographical term, 'South Asia', to describe the place where we live. The evolution of politics and geopolitics has similarly taken away 'Hindustan'. Mahatma Gandhi was an Indian citizen for hardly six months of his life; before that, he was a citizen of undivided India, which would have made him Southasian in today's parlance. Cementing icons such as the Taj Mahal have been mostly 'taken over' by state identities, and hence can be hardly projected (at least for now) as symbols for all Southasia.

You once said northern South Asia was the 'problem-child' of the region. Could you tell us more about this?

When we started Himal, we felt that Southasia was too vast, multilayered and complex to be defined only according to the 'SAARC formula' of eight nation-states. We should go beyond SAARC to include China's Tibet-linked through trade, the Sanskritic tradition, as well as Himalayan Mahayana Buddhism - as well as Burma. We should understand the penumbra of identities where the various sub-regional entities meet. We should think of people at the local government level as contributing to the Southasian sensibility. Amidst all this, we should also mark the divide or differentiation between Northern Southasia and Southern Southasia. The north is where there is massive poverty, where there are great societal polarisations, as well as where the capitals are-that is where the national security state of each of the larger countries (except Sri Lanka) is located, and where the statist vision unfolds. The north is where the wars are fought. North Southasia is where there is need for more Southasian sensibility than South Southasia.

Do you see any major differences between activists from different countries that contribute to the emergence of Southasianism? What are the main obstacles to their actions?

10 No, there are few such activists but they exist in each country, in the same proportion in each society large and small. They may not even be espousing Southasian regionalism, but they are Southasia activists because they have the 'quality of empathy' inbuilt, are practical enough to accept the nation-state but sceptical of its hubris, and have a fine understanding of the historical inter-connectedness of all of Southasia. What is missing is Southasian scholarship to back up the activists, and we therefore spend a lot of time trying to build Southasian regionalism through the SAARC formula, but with limited success. I would add that the average activist in India may have a Southasian sensibility but does not need to act on it as much, because India is already large enough to encompass much of Southasia as a region-the visceral need of the Southasian for regionalism as a link to shared history, demographic diversity and geographic spread is 
more easily available to the average citizen of the Indian nation-state. As I like to say, 'India is already much of Southasia.'

What role do you think Nepal (and its inhabitants) could play in the construction of a South Asian regionalism? What are the consequences, in your opinion, of the absence of British colonization in Nepal on the imaginary and the ideas of Nepalese people on what is or could be South Asia?

Nepal is perceived as the most 'neutral' country in Southasia, so once it gets over its own internal political challenges it could emerge as the country to provide additional impetus to the Southasian regionalism process. History has given us a country that could fill that role, but for this the Nepali intelligentsia and civil society need to come out of the nationstate mentality a bit, and be more empathetic and less ultra-nationalist. For instance, the fact that Shakyamuni Siddhartha Gautam was born in Nepal is used for a nationalistic sloganeering ('Buddha was born in Nepal') rather than for evolving a national ethos based on peace and non-violence, cooperative spirit and transparency according to the teachings of the Buddha. The fact is that Nepal is the oldest nation-state of Southasia (though nation-building is just beginning some would say), and therefore has probably some level of national self-confidence that can (or should) make it amenable to internalising regionalism more than others. But recent years of internal political buffeting and external interference have made Nepal geopolitically weak and lacking in self-confidence. If it comes out of this period of low self-esteem, it can play a major role in moving forward Southasian regionalism. Let us take three examples, entrenched in history: Nepal has the most open visa regime in Southasia, which makes Kathmandu a genuine meeting place; Nepal has a historically evolved open border with India, which stands as exemplar for the other land frontiers of Southasia; in the absence of colonisation, Nepali has been the language of discourse of the intelligentsia, which makes it possible to discuss the idea of Southasian regionalism in a vernacular language. If the concept of Southasia has to gain traction and political significance in any of our countries, then the Southasian discourse has to be carried energetically into the vernacular, which is possible in Nepal and Bangladesh more than others because of the vibrancy of the discourse in Nepali and Bangla.

What was your project about when you founded the journal Himal in 1987? What made you decide, ten years later, to transform this journal into HimalSouthasian?

12 Himal was founded in 1987 to provide long-form journalism (reportage mostly, but also essays) covering the Himalayan region. This required a cross-border format, and the imperative to evolve editorial skills attuned to a cross-border publication. As time went on, we came to realize that the economics that drives the people as well as the media tends to be north-south (for example, Nepal's linkages with the north-Indian states Uttar Pradesh and Bihar) rather than east-west along the Himalayan chain. The Himalayas as a physical entity stretch from East to West but the economic geography of the region has north-south linkages. The editors felt dissatisfied with a publication that seemed to be removed from the day-to-day interests of the subject peoples. At that point, we decided that it was important to use the same cross-border formula as the Himalayan Himal and to apply it to Southasia as a whole. This is how in 1996 Himal converted from Himalayan to Southasian.

What were the roots of your motivation to create such journals?

13 I was brought up in the liberal tradition and believing in the social-democratic ideals of B.P. Koirala of Nepal. I was then sensitised in the decade of the 1980s while living in New 
York to the power of long-form journalism and essays. Also my family tradition of seven generations of writers may have played a part, but most importantly was the spread and depth of learning of my father Kamal Mani Dixit, who is an historian, archivist and linguist who makes the perfect bridge from Southasia's past to the present. He has been my guide in many ways to a felt history-as a modern man who is also in organic touch with tradition, unlike my generation of English-educated who have been cut off.

What about the Film South Asia festival you founded in 1997? Are the main goals related to building up South Asia, and if so, how?

Driven as we were by the need to spread the Southasian consciousness in a region brought low by national ultra-nationalism, the editors of Himal decided that it was important to harness the audio-visual medium, especially its non-fiction output. We also felt that the documentary filmmakers came closest to what Himal was trying to do with its long-form reportage and essays. This is how we started the documentary festival Film Southasia, which happens every two years, while the travelling edition goes around Southasia and the world in the interim.

Cover of The Southasian Sensibility: A Himal Reader, edited by Kanak Mani Dixit (Dixit 2012).

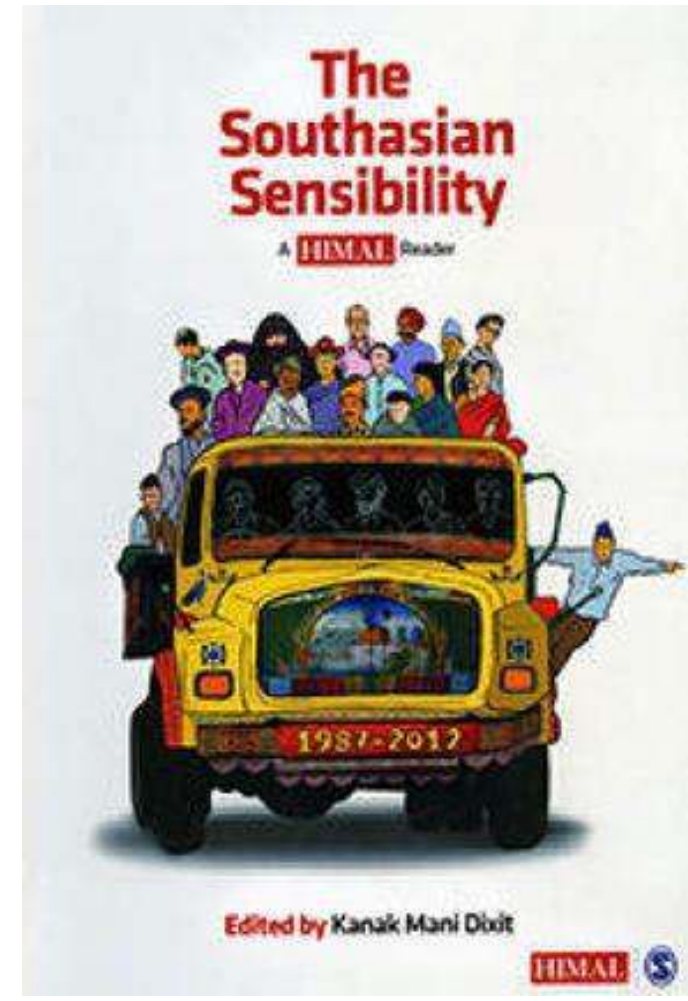

\section{BIBLIOGRAPHY}

Dixit, Kanak Mani \& Shastri Ramachandaran (2002) State of Nepal, Key Porter Books. 
Dixit, Kanak, Mani (2003) Adventures of a Nepali Frog, Rato Bangala Kitab: Kathmandu.

Dixit, Kanak, Mani (2009) Dekheko Muluk (The Country Witnessed), Jagadamba Prakashan: Kathmandu.

Dixit, Kanik Mani (2011) Peace Politics in Nepal, Kathmandu: Himal Publishers.

Dixit, Kanak Mani (ed.) (2012) The Southasian Sensibility: A Himal Reader, Sage Publications.

\section{NOTES}

1. See http://www.princeclausfund.org/en/network/kanak.html.

INDEX

Keywords: Kanak Mani Dixit, Southasianism, South Asia, Himal

\section{AUTHOR}

\section{BLANDINE RIPERT}

CNRS Research Fellow in geography and anthropology at the Centre for South Asian Studies (CEIAS), EHESS, Paris 